ЮРИСПРУДЕНЦИЯ

DOI: $10.17805 /$ trudy.2018.1.9

\title{
ГОСУДАРСТВЕННАЯ МОЛОДЕЖНАЯ ПОЛИТИКА В ОБЛАСТИ ЭЛЕКТОРАЛЬНОГО ПРОСВЕЩЕНИЯ
}

\author{
E. B. Махора \\ Московский гуманитарный университет
}

\begin{abstract}
Аннотация: Молодые избиратели определяют вектор развития своего города, региона, страны. Воспитание молодежи в области выборов - приоритетная задача государства. В соответствии этим Центральной избирательной комиссией России утверждена Молодежная электоральная концепция, направленная на реализацию новых подходов работы с молодежью.
\end{abstract}

Ключевые слова: молодежь; избиратель; электоральное просвещение; выборы

\section{STATE YOUTH POLICY IN THE FIELD OF ELECTORAL ELIMINATION OF ILLITERACY}

\author{
E. V. Makhora \\ Moscow University for the Humanities
}

\begin{abstract}
Young voters determine the vector of development of their city, region, country. Education of young people in the sphere of elections is a state priority. According to this, Youth electoral concept approved Central Election Commission of the Russian Federation, which aimed at implementation of new approaches of work with young voters approved.
\end{abstract}

Keywords: youth; voter; electoral education; elections

Электоральное просвещение - это правовое обучение и повышение правовой культуры молодых избирателей, предполагающие получение правовых знаний в области избирательного права и законодательства о выборах и референдумах. Наряду с повышением правовой культуры электоральное просвещение подразумевает и овладение навыками реализации политических прав. В связи с демографическими проблемами вопросы электорального просвещения молодежи становятся наиболее актуальными. Ведь, если в прошлое десятилетие численность молодежи в Российской Федерации увеличивалась, то теперь вплоть до 2025 г. численность будет снижаться. Согласно прогнозируемым данным к 2025 г. общая численность молодежи в Российской Федерации сократится с 35 до 25 млн человек. В этой ситуации экономическая и социальная нагрузка на российскую молодежь будет только возрастать. Таким образом, воспитание молодежи в области выборов является одной из основных задач перед государственными органами и образовательными учреждения. В соответствии с этим целью электорального просвещения является электоральная культура молодежи. 
Цель данной статьи показать основные направления государственной политики в России в области электорального просвещения молодежи.

Очевидно, что просвещение молодых избирателей нужно начинать еще в школе. Ведь с 18 лет молодой избиратель имеет право голосовать на выборах. При этом, голосуя на выборах, молодой избиратель должен делать осознанный, самостоятельный выбор, основанный на знании права и избирательной кампании.

Если в советское время молодому поколению прививали политическую культуру и особое отношение к событиям, которые происходили в жизни страны и за ее пределами, то в настоящее время молодежь не всегда доверяет политике и политикам, что и проявляется в нежелании участвовать в выборах. Также заметно снижается интерес к событиям, происходящим в стране (Сайганова, 2014: 46).

Формирование политической и правовой культуры, политическая грамотность молодежи должны быть приоритетным направлением образовательного процесса и государственной молодежной политики в целом. Ведь в интересах государства и всего общества воспитание и формирование гражданина, активно участвующего в государственной и общественной жизни.

Сегодня молодым избирателям нужно быть готовыми не только отстаивать свои права, но и выполнять свои социальные обязанности. Именно в таких условиях у молодежи необходимо сформировать должные правовые и нравственно-ценностные ориентации, соответствующие формы политического участия, гражданского поведения, высокий уровень правового сознания (Меркулов, Малик, 2016).

В мировой политической науке есть много исследований, объясняющих специфику молодежной электоральной политики. К ним относятся работы

Д. Бэкингема, С. Коулмана, С. Роу, П. Дальгрена, Р. Кимберли, Б. Д. Лоудера, Н. Смита и др. Основное внимание в них уделено формам политической самоорганизации молодежи, виртуализации политического участия в условиях информационной революции, причинам абсентеизма молодежи и методам позитивного вовлечения молодых людей в гражданскую активность (см.: Баранов, 2017). Как установлено авторами, на сегодняшний день лидирующим типом электорального поведения молодежи продолжает оставаться апатичный тип, несмотря на то, что уровень политической культуры и осведомленности молодежи в отношении политики стал смещаться в положительную сторону.

Считается, что электоральное поведение молодежи обусловлено недостатком мотивации для участия в выборах. Причем электоральное поведение молодежи зависит от таких факторов как использование средств массовой информации, от уровня политической культуры.

Центральная избирательная комиссия Российской Федерации, Российский центр обучения избирательным технологиям при ЦИК России, избирательные комиссии субъектов Российской Федерации проводят большую работу, направленную на повышение правовой культуры молодых избирателей, уровня электоральной активности и доверия молодых граждан к российской избирательной системе. Например, 4 апреля 2016 г. было подписано Соглашение по сотрудничеству Избирательной комиссии Московской области и Государственного социально-гуманитарного университета (ГСГУ). В рамках данного соглашения Избирательная комиссия Московской области и Государственный социально-гуманитарный университет бу- 
дут вести научно-исследовательскую деятельность, совместную работу по популяризации избирательного законодательства и обеспечению прохождения практики студентов. Учащиеся ГСГУ также примут участие в выборных кампаниях.

По мнению Алексея Мазурова, депутата Мособлдумы, члена Комитета по вопросам образования и культуры, на сегодняшний день среди молодых людей распространено мнение, что ходить на выборы не имеет смысла. Необходимо разъяснить, что от того, как они проголосуют, будет зависеть будущее нашей страны. Поэтому в числе прочих мероприятий в рамках образовательных программ ГСГу всем студентам вуза будет прочитан курс лекций по основам избирательного права. Подобный опыт сотрудничества с Мособлизбиркомом распространится и на другие вузы: региональная избирательная комиссия подписала соглашения ещё с 5 университетами, расположенными на территории Московской области (Алексей Мазуров: ... , 2016: Электр. ресурс).

18 октября 2017 г. в Центризбиркоме состоялась ознакомительная экскурсия для студентов Московского государственного университета имени М. В. Ломоносова. В рамках данной экскурсии студентам было рассказано об основных направлениях работы Российского центра обучения избирательным технологиям при Центральной избирательной комиссии Российской Федерации. Молодых избирателей пригласили принять участие в молодежных проектах РЦОИТ при ЦИК России (стартовавший в октябре 2017 г. конкурс видео- и аудиороликов «\#Явыбираю!» и традиционный конкурс работ по вопросам избирательного права и избирательного процесса, в котором могут принять участие студенты, аспиранты и молодые преподаватели (Студенты МГУ ... , 2017: Электр. ресурс).

На основании Решения Избирательной комиссии Московской области в 2014 г. была сформирована Молодежная избирательная комиссия Московской области. Основной ее целью является оказание содействия Избирательной комиссии Московской области в деятельности по повышению правовой культуры молодых и будущих избирателей, обучению организаторов выборов, организации выборов и референдумов на территории Московской области, формированию осознанного интереса молодых и будущих избирателей к вопросам управления государственными и местными делами посредством выборов, референдумов (Молодежная избирательная комиссия:Электронный ресурс).

Мероприятия по основным направлениям реализации Молодежной электоральной концепции связаны с правовым просвещением молодых и будущих избирателей; проводятся в рамках Дня молодого избирателя; направлены на привлечение молодежи к работе в избирательных комиссиях, на обучение молодых наблюдателей; в целом - на повышение правовой культуры молодых журналистов, освещающих ход избирательных кампаний, кампаний референдума. В данный перечень входит множество мероприятий, направленных непосредственно на молодежь, выступающую в социальной роли избирателей. К этим мероприятиям относятся различные форумы и конференции, олимпиады, конкурсы и турниры, организация «Единого дня консультаций», Всероссийская акция (флешмоб) «Встретимся на выборах!», Всероссийский конкурс селфи «\#Айданавыборы!» и другие. Общее количество мероприятий, приведенных в перечне, составляет 66 позиций. При этом ряд мероприятий являются разовыми, ряд - повторяющимися (см.: Ахматова, 2017). 
В том же 2014 г. 12 марта Центральная избирательная комиссия РФ приняла постановление «0 Молодежной электоральной концепции», (Постановление ... , Электр. ресурс). Концепция направлена на реализацию новых подходов и способов работы с молодыми избирателями в возрасте от 18 до 35 лет на основе аналитических данных с учетом имеющегося опыта и существующих на сегодняшний день направлений работы по повышению правовой культуры и электоральной активности молодых избирателей и форм взаимодействия организаторов выборов с общественными и молодежными организациями. Целями ее реализации названы в документе: повышение правовой культуры молодых избирателей; обеспечение активного и осознанного участия молодежи в избирательных кампаниях, кампаниях референдумов; повышение уровня доверия молодых граждан к российской избирательной системе, институту выборов и референдумов; преодоление политической апатии, формирование активной гражданской позиции; информирование о деятельности ЦИК России, иных избирательных комиссий, направленной на реализацию конституционных прав граждан избирать и быть избранными в органы государственной власти и органы местного самоуправления (там же).

Таким образом, очевидно, что Правительство Российской Федерации, Центральная избирательная комиссия Российской Федерации, избирательные комиссии регионов проводят активную работу просвещения молодежи в области выборов. Это приводит к положительным результатам. Например, эксперты на выборах глав регионов в 2017 г. в Северо-Западном федеральном округе отметили активность молодых избирателей в Новгородской области.

Очевидно, что после выборов Президента Российской Федерации в 2018 г. можно будет сделать наиболее полный анализ эффективности электорального просвещения молодежи, в том числе реализации Молодежной электоральной концепции ЦИК РФ.

\section{СПИСОК ЛИТЕРАТУРЫ}

Алексей Мазуров: формирование электоральной культуры молодёжи должно стать масштабной кампаний, затрагивающей не только вузы, но и школы региона (2016) [Электронный ресурс] // Официальный портал Московской областной Думы. 05 апреля. http://www.mosoblduma.ru/Press_centr/news/item/58086/ (дата обращения: 13.11.2017).

Ахматова, Д. Р. (2017) Стимуляция электоральной активности молодежи // Плехановский Барометр. № 2. С. 20-22.

Баранов, А. В. (2017) Сравнительный анализ целей и направлений электоральной политики Европейского союза и Российской Федерации в отношении молодежи // Historia provinciae - журнал региональной истории. T.1. № 3. C. 38-51. DOI 10.23859/2587-8344-2017-1-3-3

Меркулов, П. А., Малик, Е. Н. (2016) Государственная политика в сфере политической грамотности и политического воспитания Российской молодежи // Власть. № 4. С. 83-86.

Студенты МГУ им. М. В. Ломоносова ознакомились с работой ЦИК России (2017) [Электронный ресурс] // Центральная избирательная комиссия http:// www.cikrf.ru/news/cec/2017/10/18/03.html (дата обращения: 13.11.2017). 
Постановление Центральной избирательной комиссии РФ от 12 марта 2014 г. N 221/1429-6 «0 Молодежной электоральной концепции» [Электронный ресурс] // Гарант. URL: http://www.garant.ru/products/ipo/prime/ doc/70512050/\#ixzz5ABFFZvrb (дата обращения: 12.11.2017).

Сайганова Е. В. (2014) Специфика электорального поведения молодежи в структуре политической культуры общества // Известия Саратовского университета. Новая серия. Серия Социология. Политология. Т. 14. Вып. 2. С. 44-48.

Дата поступления: 15.11.2017 г.

Махора Екатерина Витальевна - аспирант кафедры философии, культурологии и политологии Московского гуманитарного университета. Адрес: 111395, Россия, г. Москва, ул. Юности, д. 5. Тел.: +7 (985) 265-43-97. Эл. адрес: katrinmak17@ rambler.ru. Научный руководитель - д-р полит. н., профессор В. И. Буренко.

Makhora Ekaterina Vitalievna, Postgraduate Student, Department of Philosophy, Culturology and Politology, Moscow University for the Humanities. Postal address: 5, Yunosti St., Moscow. Russian Federation 111395. Tel.: +7 (985) 265-43-97. E-mail: katrinmak17@rambler.ru. Scientific Adviser - V. I. Burenko, Doctor of Politology, Professor.

\section{Для цитирования:}

Махора Е. В. Государственная молодежная политика в области электорального просвещения [Электронный ресурс] // Научные труды Московского гуманитарного университета. 2018. № 1. URL: http://journals.mosgu.ru/trudy/article/view/684 (дата обращения: дд.мм.гг.). DOI: 10.17805/trudy.2018.1.9 